\title{
KERENTANAN KONSUMEN DAN PERILAKU PEMBELIAN PRODUK MAKANAN KEMASAN
}

\author{
Megawati Simanjuntak $^{1^{*}}$, Fulan Sri Utami ${ }^{1}$, Irni Rahmayani Johan ${ }^{1}$ \\ ${ }^{1}$ Departemen IImu Keluarga dan Kosumen, Fakultas Ekologi Manusia, Institut Pertanian Bogor, \\ Bogor 16680, Indonesia \\ "E-mail: mega.juntakipb@gmail.com
}

\begin{abstract}
Abstrak
Penelitian ini bertujuan untuk menganalisis pengaruh kerentanan konsumen terhadap perilaku pembelian produk makanan kemasan. Desain yang digunakan dalam penelitian ini adalah cross sectional. Contoh penelitian ini adalah sebanyak 80 rumah tangga di wilayah perdesaan dan perkotaan Bogor, Provinsi Jawa Barat yang mengonsumsi makanan kemasan. Rumah tangga tersebut dipilih secara acak sederhana. Data dianalisis secara deskriptif dan inferensia menggunakan uji beda $t$, uji regresi logistik, dan uji regresi linier berganda. Hasil penelitian menunjukkan terdapat perbedaan yang signifikan pada perilaku pembelian dan kerentanan konsumen ibu rumah tangga antara wilayah perkotaan dan wilayah perdesaan Bogor. Faktor yang memengaruhi kerentanan konsumen adalah lokasi geografi. Sementara itu, faktor-faktor yang memengaruhi perilaku pembelian produk makanan kemasan adalah pengeluaran keluarga dan kerentanan konsumen. Berdasarkan hasil penelitian, diperlukan adanya edukasi tentang cara penyelesaian permasalahan konsumen serta pengenalan dan pemberian informasi terkait badan perlindungan konsumen.
\end{abstract}

Kata kunci: kerentanan konsumen, makanan kemasan, perilaku konsumen, perilaku pembelian

\section{Consumer Vulnerability and Purchase Behavior of Food Packaging Products}

\begin{abstract}
The purpose of this study was to analyze the effect of consumer vulnerability on food packaging purchasing behavior. This study used cross sectional. The sample of this study was 80 households in Bogors' rural and urban area, West Java Province who consume food packaging product. That households was choosen by simple random sampling. Data were analyzed by descriptive, and inferential using independent samples t-test, logistic regression, and multiple linear regression. The result showed there was significant differences of households' purchasing behavior on food packaging product and consumer vulnerability in rural and urban area. Consumer vulnerability was influenced by geographical location, while purchasing behavior was influenced by family expenditure and consumer vulnerability. Based on the results, consumer education is needed on how the settlement of consumer problems and recognition as well as providing information on consumer protection agency.
\end{abstract}

Keywords: consumer behavior, consumer vulnerability, food packaging product, purchase behavior

\section{PENDAHULUAN}

Perkembangan zaman yang semakin maju menuntut segala sesuatu untuk menjadi praktis. Hal ini mendorong produsen makanan untuk menciptakan produk makanan dalam kemasan yang praktis dan ekonomis yaitu produk makanan kemasan. Produk makanan kemasan merupakan produk makanan yang dikemas atau dibungkus dalam suatu kemasan tertutup. Saat ini, sekitar 70 persen produk kemasan digunakan oleh industri makanan dan minuman. Selain itu, pada tahun 2012 industri kemasan di Indonesia tumbuh sekitar 10 persen dibandingkan tahun sebelumnya. Hal ini seiring dengan pertumbuhan industri makanan dan minuman kemasan.
Produk makanan kemasan yang beredar di Indonesia, tidak hanya berasal dari dalam negeri melainkan juga berasal dari luar negeri. Berdasarkan data Kementerian Perdagangan, jumlah impor olahan pangan pada triwulan I tahun 2011-2012 mengalami peningkatan sebesar 1,28 persen. Makanan tersebut sebagian besar diimpor dari negara-negara seperti China, Malaysia, Singapura, dan wilayah ASEAN lainnya, namun tidak sedikit produk makanan ilegal yang beredar di pasaran. Produk makanan ilegal tersebut tidak memiliki izin impor, tidak menggunakan label berbahasa Indonesia, tidak memenuhi ketentuan standar, dan tidak memiliki nomor pendaftaran. Berdasarkan hasil pengawasan 
Badan Pengawasan Obat dan Makanan (BPOM). Sebelum Idul Fitri tahun 2011, ditemukan 420 item (132.259 kemasan) makanan tidak memenuhi syarat. Dalam Koran Sindo tahun 2012 mengemukakan bahwa berdasarkan nilai ekonomi, temuan makanan tidak memenuhi syarat itu diperkirakan mencapai Rp3.306.476.000,00 dengan rincian yaitu makanan dalam keadaan rusak (3\%), dengan kadaluarsa (31\%), makanan tanpa ijin edar (44\%) dan makanan tidak memenuhi ketentuan label (22\%). Fakta-fakta tersebut menempatkkan konsumen makanan kemasan berada dalam kondisi yang rentan.

Kerentanan konsumen adalah peluang konsumen untuk mudah atau cepat dirugikan akibat ketidakseimbangan dalam interaksi pemasaran, salah satunya praktik tidak adil yang dilakukan oleh pedagang atau produsen (Mascarenhas, 2007; Baker, Gentry, \& Rittenberg, 2005). American Association of retired Persons (1993), diacu dalam Lee dan Soberon-Ferrer (1997) menyatakan bahwa kerentanan konsumen dapat dilihat dari empat dimensi, yaitu pengetahuan konsumen tentang sumber informasi mengenai cara penyelesaian permasalahan konsumen, pengetahuan tentang hak-hak konsumen, keterbukaan praktik perdagangan, dan pengetahuan tentang perdagangan yang menyesatkan. Adkins dan Ozzane (2005) juga menganalisis kerentanan konsumen dengan aspek yang tidak jauh berbeda yaitu pengetahuan tentang hak konsumen dan praktik pemasaran, serta keterampilan interpersonal untuk mengajukan protes (Adkins \& Ozzane, 2005). Selain itu, kerentanan konsumen juga dapat dijelaskan berdasarkan dua paradigma yaitu defisiensi pengetahuan dan interaksi sosial, sehingga orang yang lebih tua cenderung rentan karena mengalami penurunan kognitif dan isolasi sosial (Langerderfer \& Shrimp, 2001).

Hasil kajian empiris tentang kerentanan konsumen mengindikasikan keterkaitan dengan beberapa faktor. Kerentanan konsumen dipengaruhi oleh karakteristik konsumen (usia, status pernikahan, pendidikan), pengetahuan, dan paradigma sosial (Lee \& Soberon-Ferrer, 1997). Selain itu, tingkat literasi juga dikaitkan dengan kerentanan, yang mana konsumen yang memiliki kemampuan terbatas dalam memproses informasi cenderung rentan terhadap penipuan (Adkins \& Ozzane, 2005). Bahkan ketika konsumen berpikir bahwa semua atau kebanyakan produk dalam satu kategori adalah sama atau serupa, maka hal tersebut dapat mengakibatkan beberapa kesalahan, diantaranya kesalahan dalam pembelian, penyalahgunaan produk, kesalahpahaman produk atau misattribution berbagai atribut produk yang menghasilkan maksimalisasi nonutilitas dan kerentanan konsumen (Walsh et al., 2010).

Kerentanan konsumen diduga berpengaruh terhadap perilaku pembelian konsumen di perkotaan dan perdesaan karena perbedaan karakteristik konsumen di kedua wilayah. Konsumen di daerah perkotaan dan perdesaan menunjukkan kecenderungan perilaku pembelian yang berbeda (Zameer, Saeed \& Abass, 2012). Konsumen di perdesaan pada umumnya memiliki pendapatan yang rendah, memiliki tingkat literasi yang rendah, memiliki kesadaran terhadap merek yang rendah, mendapatkan informasi yang tidak seimbang serta fasilitas komunikasi dan transportasi yang tidak memadai (Kumar \& Joseph, 2014). Rendahnya pendapatan per kapita di perdesaan menyebabkan rendahnya pengeluaran untuk membeli makanan kemasan (Craig \& Douglas, 2011).

Hasil studi Anilkumar dan Joseph (2015) menemukan perbedaan rumah tangga di perdesaan dan perkotaan. Rumah tangga di perdesaan mencukupi kebutuhan pangan dengan makanan hasil pertanian yang dikelola. Konsumen di perdesaan juga cenderung kurang komunikatif, konservatif (berorientasi pada kepuasan), mencintai nilai-nilai tradisional, mengambil keputusan secara lambat, memiliki kemampuan belajar dan mengevaluasi yang lambat, serta sensitif terhadap harga. Konsumen di perkotaan cenderung memiliki anggota keluarga yang sedikit, memiliki tingkat pendidikan yang tinggi, melek internet, intensif dalam menggunakan alat komunikasi, inovatif, memiliki gaya hidup modern, memiliki banyak pengalaman, individualistis dan memiliki tekanan waktu, berkeinginan untuk mencoba dan menerima hal baru, mencintai bumi, lebih sensitif terhadap atribut produk dibandingkan dengan loyalitas terhadap merek.

Fakta-fakta di atas menunjukkan bahwa kerentanan konsumen dan kaitannya dengan perilaku pembelian menjadi topik yang menarik untuk dikaji. Studi terdahulu belum mengkaji keterkaitan antara kerentanan konsumen dengan perilaku pembelian, khususnya pada makanan kemasan. Dengan demikian, kajian ini memiliki kebaruan dalam mengaitkan kedua variabel tersebut dan fokusnya pada makanan kemasan. Kerentanan konsumen merupakan salah satu tolak ukur yang menunjukkan kuat atau tidaknya posisi konsumen di pasaran. 
Konsumen yang memiliki kemampuan yang terbatas dalam memproses informasi lebih rentan. Ketika konsumen rentan, maka peluang membeli atau mengonsumsi produk tanpa pertimbangan yang baik dan matang akan semakin besar. Selain itu, konsumen yang rentan akan semakin mudah ditipu atau mengalami praktik pemasaran yang tidak adil, sehingga akan semakin melemahkan posisinya di pasar. Berdasarkan uraian di atas, kerentanan konsumen diduga memiliki hubungan dengan perilaku pembelian produk makanan kemasan di wilayah perkotaan dan perdesaan.

Karakteristik konsumen di perkotaan dan perdesaan telah diteliti oleh Craig dan Douglas (2011); Kumar dan Joseph (2014); serta Anilkumar dan Joseph (2015) yang mengindikasikan bahwa karakteristik konsumen di kedua wilayah tersebut berbeda. Perilaku pembelian rumah tangga di perkotaan dan perdesaan juga telah diteliti sebelumnya oleh Zameer, Saeed, dan Abass (2012) yang juga menunjukkan adanya perbedaan di kedua wilayah tersebut. Oleh karena itu, penelitian ini mengkaji kerentanan konsumen di perkotaan dan perdesaan sekaligus mempelajari keterkaitannya dengan karakteristik konsumen, dan perilaku pembelian di dua lokasi dengan karakteristik geografis yang berbeda tersebut.

Berdasarkan uraian tentang perbedaan karakteristik antara konsumen di kedua wilayah tersebut, maka diduga terdapat perbedaan pula pada kerentanan konsumen dan perilaku pembelian produk makanan kemasan. Oleh karena itu, penelitian ini bertujuan untuk: (1) mengidentifikasi karakteristik keluarga pengguna produk makanan kemasan di wilayah perkotaan dan perdesaan; (2) menganalisis kerentanan konsumen keluarga di wilayah perkotaan dan perdesaan; (3) menganalisis perilaku pembelian produk makanan kemasan keluarga di wilayah perkotaan dan perdesaan; (4) menganalisis pengaruh karakteristik keluarga terhadap, kerentanan konsumen; dan (5) menganalisis pengaruh karakteristik keluarga dan kerentanan konsumen terhadap perilaku pembelian produk makanan kemasan.

\section{METODE}

Jenis penelitian ini merupakan penelitian deskriptif dengan desain cross sectional. Lokasi penelitian dipilih secara purposive yaitu Kabupaten dan Kota Bogor, Provinsi Jawa Barat. Kabupaten Bogor dipilih karena mewakili lokasi geografis perdesaan dengan pertimbangan merupakan kabupaten terbanyak penduduknya di Provinsi Jawa Barat. Sementara itu, Kota Bogor dipilih karena mewakili lokasi geografis wilayah perkotaan dengan pertimbangan yang sama dengan Kabupaten Bogor, namun lebih kosmopolit dibandingkan dengan Kabupaten Bogor. Pemilihan kecamatan, desa atau kelurahan, RW, dan RT dilakukan secara acak yang menghasilkan Kelurahan Empang, Kecamatan Bogor Selatan sebagai perwakilan daerah perkotaan dan Desa Ciaruteun Ilir, Kecamatan Cibungbulang sebagai perwakilan daerah perdesaan.

Populasi penelitian adalah seluruh keluarga lengkap yang pernah membeli makanan kemasan selama tiga bulan terakhir. Teknik pengambilan contoh menggunakan probability sampling berupa random sampling. Contoh penelitian meliputi rumah tangga di wilayah perkotaan dan perdesaan Kota dan Kabupaten Bogor, masing-masing 40 ibu rumah tangga, sehingga total contoh dari kedua wilayah adalah 80 keluarga. Penentuan ibu rumah tangga sebagai responden dalam penelitian didasarkan atas perannya sebagai orang yang bertanggung jawab dalam menentukan keputusan (gate keeper) pemilihan dan persiapan makanan bagi seluruh anggota keluarga, sekaligus berperan aktif dalam memberikan inisiatif pemikiran saat pembelian produk dan pengumpulan informasi untuk membantu pengambilan keputusan pangan (Engel, Blackwell, \& Miniard, 1995)

Data diperoleh dari wawancara langsung kepada responden dengan alat bantu kuesioner. Variabel yang diteliti dalam penelitian ini meliputi karakteristik keluarga, kerentanan konsumen, dan perilaku pembelian. Karakteristik keluarga terdiri atas usia, pendidikan, besar keluarga, pendapatan, pengeluaran, dan letak geografis. Perilaku pembelian produk makanan kemasan terdiri atas jenis produk makanan kemasan yang dibeli, frekuensi pembelian, tempat pembelian, waktu pembelian, pelaku pembelian, kebiasaan menyimpan produk makanan kemasan, pertimbangan merek produk makanan kemasan, ketertarikan terhadap produk makanan kemasan daripada nonkemasan yang sejenis, dan perencanaan pembelian produk makanan kemasan.

Kerentanan konsumen yang diukur dengan memodifikasi instrumen The Vulnerability Index (VI) yang diacu dari penelitian American Association of Retired Persons (AARP). Kerentanan konsumen terdiri atas tiga dimensi yaitu pengetahuan tentang sumber informasi 

mengatasi permasalahan konsumen (4 pertanyaan), pengetahuan tentang hak-hak konsumen ( 5 pertanyaan), dan keterbukaan praktik perdagangan (3 pertanyaan). Kerentanan konsumen diukur dengan skala Guttman Ya (skor 1) dan Tidak (skor 0). Instrumen kerentanan konsumen memiliki nilai Cronbachs' alpha sebesar 0,567. Kerentanan konsumen dikategorikan menjadi rentan (indeks 51-100) dan tidak rentan (indeks 0-50).

Analisis data meliputi analisis deskriptif dan inferensia. Analisis deskriptif meliputi frekuensi, rata-rata, standar deviasi, nilai minimum, dan nilai maksimum. Analisis inferensia yang dilakukan dalam penelitian ini yaitu uji beda $t$-Test, uji regresi logistik, dan uji linier berganda.

\section{HASIL}

\section{Karakteristik Keluarga}

Rata-rata jumlah anggota keluarga di wilayah perkotaan dan perdesaan adalah empat orang. Hasil yang diperoleh ini sejalan dengan BKKBN (1996) yang menyimpulkan bahwa rata-rata rumah tangga di perkotaan maupun perdesaan termasuk dalam kategori keluarga kecil yaitu memiliki jumlah anggota keluarga kurang dari atau sama dengan empat orang. Jumlah anggota kleuarga antara keluarga di perkotaan dan perdesaan tidak berbeda signifikan $(p>0,05)$.

Rata-rata usia suami di wilayah perkotaan adalah 39,4 tahun dan di wilayah perdesaan adalah 38,3 tahun. Selanjutnya, usia istri di wilayah perkotaan adalah 33,7 tahun dan di wilayah perdesaan adalah 34,2 tahun. Usia suami dan isteri termasuk dalam kategori dewasa awal (18-40 tahun). Usia suami dan isteri di wilayah perkotaan dan perdesaan tidak berbeda signifikan $(p>0,05)$.

Suami di wilayah perkotaan menempuh pendidikan selama 9,3 tahun, sedangkan suami di wilayah perdesaan menempuh pendidikan selama 5,8 tahun. Pendidikan suami antara suami di wilayah perkotaan dan perdesaan berbeda signifikan. Suami di wilayah perkotaan memiliki lama pendidikan yang lebih tinggi dibandingkan dengan suami di wilayah perdesaan. Demikian juga halnya dengan pendidikan istri. Pendidikan istri antara istri di wilayah perkotaan dan perdesaan berbeda signifikan. Rata-rata lama pendidikan istri di wilayah perkotaan $(9,1$ tahun) lebih tinggi dibandingkan dengan lama pendidikan istri di wilayah perdesaan (5,3 tahun)
Pendapatan keluarga antara keluarga di wilayah perdesaan dan perkotaan tidak berbeda signifikan $(p>0,05)$. Rata-rata pendapatan keluarga di wilayah perkotaan adalah Rp388.930,00/kapita/bulan, sedangkan ratarata pendapatan keluarga di wilayah perdesaan adalah Rp356.488,09/kapita/bulan. Pengeluaran keluarga juga tidak berbeda signifikan antara keluarga di wilayah perkotaan dan perdesaan $(p>0,05)$. Rata-rata pengeluaran keluarga di wilayah perkotaan adalah Rp298.903,57/kapita/bulan dan rata-rata pengeluaran keluarga di wilayah perdesaan adalah sebesar Rp255.515,71/kapita/bulan.

\section{Kerentanan Konsumen}

Kerentanan konsumen diukur berdasarkan tiga dimensi yaitu pengetahuan tentang sumber informasi mengatasi permasalahan konsumen, pengetahuan tentang hak-hak konsumen, dan keterbukaan praktik perdagangan. Sebaran, nilai rata-rata, standar deviasi, dan koefisien uji beda berdasarkan dimensi kerentanan konsumen pada ibu rumah tangga di wilayah perdesaan dan perkotaan disajikan pada Tabel 1.

Dimensi pengetahuan tentang sumber informasi mengatasi permasalahan pada konsumen. Hasil pada Tabel 1 menunjukkan bahwa dimensi pengetahuan tentang sumber informasi mengatasi permasalahan konsumen terdiri atas empat pertanyaan, tetapi perbedaan yang signifikan $(p<0,01)$ antara ibu rumah tangga di perkotaan dan perdesaan hanya terlihat pada tiga item. Sebanyak 5 persen ibu rumah tangga di perkotaan mengetahui bahwa terdapat badan penyelesaian sengketa konsumen untuk menyelesaikan permasalahan konsumen, sementara di perdesaan tidak ada ibu rumah tangga yang mengetahui hal tersebut. Sebanyak 37,5 persen ibu rumah tangga di perkotaan mengetahui bahwa ada lembaga atau yayasan perlindungan konsumen, sementara tidak ada ibu rumah tangga di perdesaan yang mengetahui hal tersebut. Sebanyak 82,5 persen ibu rumah tangga di perkotaan mengetahui langkah-langkah menyelesaikan permasalahan konsumen, sedangkan di perdesaan hanya 37,5 persen ibu rumah tangga saja yang mengetahui hal tersebut.

Berdasarkan hasil pengkategorian, persentase ibu rumah tangga di perdesaan yang tergolong rentan $(87,5 \%)$ lebih besar dibandingkan dengan di perkotaan (50\%). Hasil uji beda juga menunjukkan adanya perbedaan signifikan $(p<0,01)$ antara ibu rumah tangga di perkotaan dan di perdesaan pada dimensi ini, 

yang mana rata-rata indeks di wilayah perkotaan lebih rendah $(58,75 \pm 25,03)$ dibandingkan dengan wilayah perdesaan $(82,50 \pm 17,17)$. Hal ini menunjukkan bahwa ibu rumah tangga di perdesaan cenderung belum mengetahui tentang badan penyelesaian sengketa konsumen dan lembaga perlindungan konsumen, serta belum mengetahui langkahlangkah menyelesaikan permasalahan dengan penjual. Keterbatasan pengetahuan ini mungkin karena masih kurangnya akses informasi tentang badan atau lembaga perlindungan konsumen di wilayah perdesaan. Selain itu, kesadaran ibu rumah tangga di perdesaan untuk mengajukan komplain jika bermasalah dengan penjual atau produsen juga masih rendah. Dengan demikian, ibu rumah tangga di perdesaan lebih rentan mengalami kerugian dalam interaksi jual beli.

Dimensi pengetahuan tentang hak-hak konsumen. Hasil penelitian menunjukkan bahwa lebih dari separuh (52,5\%) ibu rumah tangga di perkotaan dan sebesar 7,5 persen ibu rumah tangga di perdesaan mengetahui adanya undang-undang yang mengatur mengenai perlindungan konsumen (Tabel 1). Seluruh ibu rumah tangga di perkotaan sudah mengetahui hak-hak sebagai konsumen. Hakhak konsumen tersebut antara lain yaitu hak untuk mendapatkan informasi yang jelas, benar, dan jujur terkait barang dan jasa, hak mengikuti upaya penyelesaian hukum sengketa perlindungan konsumen, dan berhak mengajukan kritik, saran maupun komplain kepada penjual atau produsen jika dirugikan. Hampir seluruh ibu rumah tangga di perdesaan juga telah menyadari bahwa sebagai konsumen berhak mendapatkan informasi dan mengajukan kritik, saran, dan komplain jika dirugikan penjual atau pedagang. Lebih dari dua pertiga $(67,5 \%)$ ibu rumah tangga di perdesaan mengetahui bahwa konsumen berhak untuk mengikuti upaya penyelesaian hukum sengketa perlindungan konsumen secara benar.

Hasil pengkategorian pada dimensi pengetahuan tentang hak-hak konsumen menunjukkan bahwa hampir seluruh ibu rumah tangga, baik di wilayah perkotaan (100\%) maupun perdesaan $(97,5 \%)$ sudah mengetahui hak-hak konsumen. Hasil uji beda juga menunjukkan ada perbedaan signifikan $(p<0,05)$ antara kedua wilayah, yang terlihat dari rata-rata indeks dimensi pengetahuan tentang hak-hak konsumen di wilayah perkotaan $(10,00 \pm 10,13)$ lebih kecil dibandingkan dengan wilayah perdesaan $(27,50 \pm 16,13)$. Hal ini menunjukkan bahwa ibu rumah tangga di perdesaan lebih rentan dibandingkan dengan ibu rumah tangga di perkotaan. Pengetahuan tentang hak-hak konsumen ini berguna untuk melindungi konsumen jika dirugikan, seperti mendapatkan informasi yang tidak benar, tidak menerima barang sesuai kesepakatan atau menerima barang dalam kondisi yang rusak atau cacat. Namun, kesadaran konsumen untuk memperjuangkan hak-hak sebagai konsumen masih tergolong rendah. Berdasarkan hasil wawancara, beberapa ibu rumah tangga cenderung pasif dan tidak mau mengajukan kritik atau komplain ke pedagang atau produsen jika dirugikan pada waktu pembelian makanan kemasan. Beberapa ibu rumah tangga menganggap bahwa harga produk makanan kemasan masih bisa dijangkau dan merasa keberatan untuk mengajukan komplain, karena biaya yang dikeluarkan untuk mengajukan komplain tidak sebanding dengan ganti rugi yang didapatkan.

Dimensi keterbukaan praktik. Tabel 1 menunjukkan terdapat perbedaan yang signifikan antara ibu rumah tangga di perkotaan dan perdesaan dalam hal kesadaran untuk memperhatikan penjelasan dan promosi yang dilakukan pedagang. Sebagian besar $(85 \%)$ ibu rumah tangga di wilayah perkotaan menyadari bahwa sebagai konsumen harus memperhatikan penjelasan dan promosi yang dilakukan pedagang, sedangkan hanya 60 persen ibu rumah tangga di perdesaan yang menyadari hal tersebut. Sementara itu, lebih dari separuh ibu rumah tangga di perkotaan $(57,5 \%)$ dan di perdesaan (55\%) menyatakan bahwa konsumen dan pedagang harus samasama terbuka dalam proses pembelian. Separuh ibu rumah tangga di perkotaan $(50 \%)$ dan lebih dari separuh ibu rumah tangga di perdesaan $(55 \%)$ menyatakan bahwa pedagang dalam mempromosikan produk dilakukan secara benar dan jujur.

Hasil pengkategorian kerentanan konsumen pada dimensi keterbukaan praktik perdagangan mengindikasikan sebesar 57,5 persen ibu rumah tangga di wilayah perkotaan dan sebesar 55 persen ibu rumah tangga di wilayah perdesaan tergolong tidak rentan. Hasil penelitian juga menunjukkan bahwa dimensi keterbukaan praktik perdagangan di wilayah perkotaan dan perdesaan berbeda signifikan $(p<0,01)$, yang mana rata-rata indeks dimensi tersebut di wilayah perkotaaan $(35,83 \pm 33,24)$ lebih kecil dibandingkan dengan di wilayah perdesaan $(42,50 \pm 39,21)$. Hal tersebut menunjukkan bahwa ibu rumah tangga di perdesaan cenderung rentan dibandingkan di wilayah perkotaan. Sebagian besar ibu rumah 

tangga di perkotaan maupun perdesaan sudah memiliki kesadaran untuk memperhatikan penjelasan atau promosi dari pedagang. Namun, beberapa ibu rumah tangga di perkotaan maupun perdesaan meyakini jika masih ada ketidakterbukaan dalam proses pembelian. Ibu rumah tangga menilai bahwa masih ada beberapa pedagang yang tidak jujur dalam proses jual-beli.

Kerentanan konsumen terdiri atas tiga dimensi. Jika dilihat secara keseluruhan, sebagian besar (90\%) ibu rumah tangga di perkotaan dan hampir dua pertiga $(62,5 \%)$ ibu rumah tangga di perdesaan termasuk dalam kategori tidak rentan. Namun, persentase kerentanan ibu rumah tangga di wilayah perdesaan yang termasuk pada kategori rentan
$(37,5 \%)$ lebih banyak daripada ibu rumah tangga di wilayah perkotaan (10\%). Hasil uji beda juga menunjukkan bahwa terdapat perbedaan yang signifikan $(p<0,01)$ pada kerentanan konsumen di kedua wilayah, dengan rata-rata indeks kerentanan konsumen di perdesaan lebih tinggi $(49,58 \pm 14,37)$ dibandingkan di perkotaan $(32,71 \pm 15,72)$. Berdasarkan sebaran data dan nilai rata-rata, dapat dilihat bahwa ibu rumah tangga di perdesaan cenderung lebih rentan dibandingkan dengan ibu rumah tangga di perkotaan. Adapun dimensi yang berkontribusi paling besar menyebabkan kerentanan konsumen di wilayah perdesaan adalah pengetahuan tentang sumber informasi cara mengatasi permasalahan konsumen yang masih rendah.

Tabel 1 Sebaran, nilai rata-rata, standar deviasi, dan koefisien uji beda berdasarkan dimensi kerentanan konsumen pada ibu rumah tangga di wilayah perdesaan dan perkotaan

\begin{tabular}{|c|c|c|c|c|}
\hline No & Pernyataan & $\begin{array}{l}\text { Perkotaan } \\
\quad(\%)\end{array}$ & $\begin{array}{l}\text { Perdesaan } \\
\quad(\%)\end{array}$ & $p$-value \\
\hline & $\begin{array}{l}\text { Pengetahuan tentang sumber informasi mengatasi per- } \\
\text { masalahan konsumen }\end{array}$ & & & \\
\hline 1 & $\begin{array}{l}\text { Informasi tentang makanan kemasan tidak sepenuhnya } \\
\text { bermanfaat bagi saya sebagai konsumen. }\end{array}$ & 40,0 & 30,0 & 0,075 \\
\hline 2 & $\begin{array}{l}\text { Saya mengetahui adanya badan penyelesaian sengketa } \\
\text { konsumen untuk menyelesaikan permasalahan yang dialami } \\
\text { konsumen. }\end{array}$ & 5,0 & 0,0 & $0,003^{\star *}$ \\
\hline 3 & $\begin{array}{l}\text { Ada lembaga atau yayasan perlindungan konsumen di Indonesia } \\
\text { membantu konsumen untuk menyelesaikan masalahnya. }\end{array}$ & 37,5 & 0,0 & $0,000^{* *}$ \\
\hline \multirow[t]{3}{*}{4} & $\begin{array}{l}\text { Konsumen mengetahui langkah-langkah menyelesaikan } \\
\text { permasalahan dengan penjual. }\end{array}$ & 82,5 & 37,5 & $0,000^{* *}$ \\
\hline & Rata-rata \pm Standar deviasi (indeks) & $\begin{array}{c}58,75 \pm \\
25,03\end{array}$ & $\begin{array}{c}82,50 \pm \\
17,17\end{array}$ & $0,000^{* *}$ \\
\hline & Pengetahuan tentang hak-hak konsumen & & & \\
\hline 1 & $\begin{array}{l}\text { Ada undang-undang yang mengatur mengenai perlindungan } \\
\text { konsumen di Indonesia. }\end{array}$ & 52,5 & 7,5 & $0,000^{* *}$ \\
\hline 2 & $\begin{array}{l}\text { Konsumen memiliki hak untuk mendapatkan informasi jelas, } \\
\text { benar, jujur mengenai kondisi barang dan jasa. }\end{array}$ & 100 & 97,5 & $0,043^{\star}$ \\
\hline 3 & $\begin{array}{l}\text { Konsumen berhak untuk mengikuti upaya penyelesaian hukum } \\
\text { sengketa perlindungan konsumen secara patut. }\end{array}$ & 100 & 67,5 & $0,000^{* *}$ \\
\hline 4 & $\begin{array}{l}\text { Konsumen berhak untuk mengajukan krititk, saran maupun } \\
\text { komplain kepada penjual atau produsen jika barang yang dibeli } \\
\text { mengalami kecacatan. }\end{array}$ & 100 & 95,0 & $0,003^{* *}$ \\
\hline \multirow[t]{4}{*}{5} & $\begin{array}{l}\text { Konsumen berhak untuk mendapatkan ganti rugi apabila barang } \\
\text { yang diterima tidak sesuai dengan perjanjian atau tidak } \\
\text { sebagaimana mestinya. }\end{array}$ & 100 & 95,0 & $0,003^{* *}$ \\
\hline & Rata-rata \pm Standar deviasi (indeks) & $10,0 \pm$ & $27,50 \pm$ & $0,043^{*}$ \\
\hline & & 10,13 & 16,13 & \\
\hline & Keterbukaan praktik perdagangan & & & \\
\hline 1 & $\begin{array}{l}\text { Konsumen memperhatikan penjelasan dan promosi yang } \\
\text { dilakukan pedagang. }\end{array}$ & 85,0 & 60,0 & $0,000^{* *}$ \\
\hline 2 & $\begin{array}{l}\text { Konsumen dan pedagang sama-sama terbuka dalam proses } \\
\text { pembelian. }\end{array}$ & 57,5 & 55,0 & 0,663 \\
\hline \multirow[t]{2}{*}{3} & $\begin{array}{l}\text { Pedagang dalam mempromosikan produknya dilakukan secara } \\
\text { jujur dan apa adanya }\end{array}$ & 50,0 & 55,0 & 0,532 \\
\hline & Rata-rata \pm Standar deviasi (indeks) & $\begin{array}{c}35,83 \pm \\
33,24\end{array}$ & $\begin{array}{c}42,50 \pm \\
39,21\end{array}$ & $0,000^{* *}$ \\
\hline
\end{tabular}

Keterangan: *signifikan pada $\mathrm{p}<0,05 ;{ }^{* *}$ signifikan pada $\mathrm{p}<0,01$ 



\section{Perilaku Pembelian Makanan Kemasan}

Perilaku pembelian makanan kemasan dapat dilihat dari jenis makanan yang sering dibeli oleh rumah tangga. Berdasarkan hasil survei sebelum penelitian, jenis-jenis makanan kemasan yang sering dikonsumsi rumah tangga antara lain produk susu dan olahannya, makanan ringan, makanan kaleng, makanan bayi, dan mie instan. Hampir seluruh (95\%) rumah tangga di perkotaan melakukan pembelian produk mie instan dan makanan ringan dan sebesar 77,5 persen membeli produk susu dan olahannya.

Sebagian besar rumah tangga di perdesaan membeli mie instan $(97,5 \%)$, produk susu dan olahannya (90\%) serta makanan ringan $(85 \%)$. Sementara itu, kurang dari dua pertiga ibu rumah tangga baik di perkotaan dan perdesaan membeli produk makanan kaleng (kota 60\%; desa 32,5\%) dan makanan bayi (kota 17,5\%; desa 7,5\%). Berdasarkan uraian di atas dapat dikatakan bahwa sebagian besar rumah tangga baik di perkotaan maupun perdesaan membeli produk susu dan olahannya, makanan ringan, dan mie instan. Oleh karena itu, untuk pembahasan selanjutnya difokuskan pada ketiga produk dengan persentase tertinggi tersebut.

\section{Frekuensi Pembelian Produk Makanan Ke- masan}

Hasil penelitian menunjukkan bahwa 62,5 persen ibu rumah tangga di perkotaan dan 82,5 persen di perdesaan membeli produk susu dan olahannya sebanyak 1 sampai 25 kali dalam sebulan, dengan rata-rata kurang lebih 8 kali $(7,60 \pm 10,094)$ per bulan untuk di perkotaan dan 5 kali $(4,90 \pm 7,396)$ per bulan untuk di perdesaan. Demikian pula dengan makanan ringan, sebesar 65 persen rumah tangga di perkotaan dan perdesaan membeli makanan ringan pada rentang frekuensi yang sama, dengan rata-rata di perkotaan 12 kali per bulan $(12,10 \pm 13,551)$ dan di perdesaan 8 kali per bulan $(8,20 \pm 11,257)$. Sebanyak 70 persen ibu rumah tangga di perkotaan dan 85 persen di perdesaan membeli mie instan pada rentang frekuensi yang sama, dengan rata-rata masingmasing sebanyak 12 kali $(12,30 \pm 11,375)$ dan 9 kali $(8,78 \pm 9,319)$ per bulan. Hasil uji beda menunjukkan bahwa frekuensi pembelian susu, makanan ringan, dan mie instan tidak berbeda signifikan antara wilayah perkotaan dan perdesaan. Artinya, frekuensi pembelian ketiga makanan kemasan tersebut cenderung sama antara konsumen di perkotaan dan perdesaan.

\section{Pengeluaran per Kapita Produk Makanan Kemasan}

Pengeluaran per kapita produk makanan kemasan dikategorikan menjadi 3 yaitu kategori rendah (Rp25.000,00-Rp196.668,00), kategori sedang (Rp196.669,00-Rp368.334,00), dan kategori tinggi (Rp368.335,00-Rp540.000,00). Hasil penelitian menunjukkan bahwa hampir dua pertiga $(62,5 \%)$ rumah tangga di perkotaan dan sebagian besar (85\%) rumah tangga di perdesaan mengeluarkan biaya untuk makanan kemasan pada kategori rendah. Tidak ada responden di perdesaan yang memiliki pengeluaran pada kategori tinggi. Sebanyak 15 persen rumah tangga di perkotaan memiliki pengeluaran untuk makanan kemasan termasuk dalam kategori tinggi. Hasil uji beda menunjukkan bahwa terdapat perbedaan yang signifikan $(p<0,01)$ pada pengeluaran makanan kemasan antara wilayah perkotaan dan perdesaan, dimana rata-rata pengeluaran per kapita produk makanan kemasan di wilayah perkotaan adalah sebesar Rp196.037,00 dan di wilayah perdesaan sebesar Rp108.837,00.

\section{Analisis Pengaruh Karakteristik Keluarga terhadap Kerentanan Konsumen}

Hasil analisis pengaruh karakteristik keluarga terhadap kerentanan konsumen disajikan pada Tabel 2. Analisis dilakukan dengan menggunakan uji regresi logistik dengan $Y$ adalah kerentanan konsumen $(0$ untuk konsumen tidak rentan dan 1 untuk konsumen rentan). Variabel bebas yang termasuk dalam model adalah usia responden, besar keluarga, lokasi geografis, lama pendidikan, pendapatan per kapita keluarga, pengeluaran per kapita keluarga, dan pengeluaran makanan kemasan per kapita.

Hasil uji untuk variabel yang memengaruhi kerentanan konsumen menghasilkan koefisien determinasi (Nagelkekre $R$ square) sebesar 0,304 , yang berarti 30,4 persen kerentanan konsumen dapat dijelaskan oleh variabel yang ada dalam model dan 69,6 persen sisanya dijelaskan oleh variabel lain yang tidak diteliti dalam penelitian ini. Hasil analisis yang disajikan pada tabel 2 menunjukkan bahwa kerentanan konsumen dipengaruhi secara signifikan oleh lokasi geografis $(p<0,05)$. Lokasi geografis berpengaruh signifikan negatif terhadap kerentanan konsumen. Hal ini menunjukkan bahwa peluang untuk mengalami kerentanan bagi ibu rumah tangga yang tinggal di wilayah perkotaan adalah 4,81 kali lebih rendah dibandingkan dengan ibu rumah tangga yang tinggal di wilayah perdesaan. 

Tabel 2 Koefisien regresi untuk analisis pengaruh karakteristik keluarga terhadap kerentanan konsumen

\begin{tabular}{|c|c|c|c|}
\hline \multirow[t]{2}{*}{ Variabel Bebas } & \multicolumn{3}{|c|}{$\begin{array}{c}\text { Kerentanan Konsumen } \\
(1=\text { rentan, } 0=\text { tidak rentan })\end{array}$} \\
\hline & $B$ & Sig & $\operatorname{Exp}(B)$ \\
\hline $\begin{array}{l}\text { Usia responden } \\
\text { (tahun) }\end{array}$ & $-0,072$ & 0,077 & 0,930 \\
\hline $\begin{array}{l}\text { Besar keluarga } \\
\text { (orang) }\end{array}$ & 0,027 & 0,931 & 1,027 \\
\hline $\begin{array}{l}\text { Lokasi geografis } \\
\text { (1=perkotaan, } \\
0=\text { perdesaan) }\end{array}$ & $-1,570$ & $0,044^{*}$ & 0,208 \\
\hline $\begin{array}{l}\text { Lama pendidikan } \\
\text { responden } \\
\text { (tahun) }\end{array}$ & 0,639 & 0,555 & 1,894 \\
\hline $\begin{array}{l}\text { Pendapatan total } \\
\text { keluarga } \\
\text { (Rp/kap/bulan) }\end{array}$ & 0,000 & 0,360 & 1,000 \\
\hline $\begin{array}{l}\text { Nagelkekre } R \\
\text { Square }\end{array}$ & & 0,304 & \\
\hline Sig. & & $0,000^{* *}$ & \\
\hline
\end{tabular}

\section{Analisis Pengaruh Karakteristik Keluarga dan Kerentanan Konsumen terhadap Perilaku Pembelian Makanan Kemasan}

Pengaruh karakteristik keluarga dan kerentanan konsumen terhadap perilaku pembelian makanan kemasan dianalisis menggunakan uji regresi linear berganda. Hasil analisis disajikan pada Tabel 3. Model yang dianalisis memiliki koefisian determinasi yang telah disesuaikan (Adjusted $R$ square) sebesar 0,213 pada susu dan olahannya, 0,176 pada makanan ringan, 0,054 pada mie instan, dan 0,263 pada pengeluaran makanan kemasan secara keseluruhan. Hal ini menunjukkan bahwa sebesar 21,3 persen variabel pengeluaran susu dan olahannya, 17,6 persen variabel pengeluaran makanan ringan, 5,4 persen variabel pengeluaran mie instan, dan 26,3 persen variabel pengeluaran makanan kemasan dapat dijelaskan oleh variabel independen yang dimasukkan pada masingmasing model.

Pada makanan ringan, variabel independen yang berpengaruh terhadap pengeluaran makanan kemasan secara signifikan adalah pengeluaran keluarga ( $\beta=$ 0,$405 ; \quad p<0,05$ ). Pada produk susu dan olahannya, pengeluaran susu dan olahannya dipengaruhi oleh kerentanan konsumen $(\beta=-$ $0,341 ; p<0,01)$. Variabel yang berpengaruh terhadap pengeluaran makanan kemasan secara signifikan adalah kerentanan konsumen $(\beta=-0,362 ; p<0,05)$.
Tabel 3 Koefisien regresi untuk analisis pengaruh karakteristik keluarga dan kerentanan konsumen terhadap perilaku pembelian makanan

\begin{tabular}{|c|c|c|c|c|}
\hline $\begin{array}{l}\text { Variabel } \\
\text { bebas }\end{array}$ & A & B & C & $\mathrm{D}$ \\
\hline $\begin{array}{l}\text { Usia istri } \\
\text { (tahun) }\end{array}$ & $-0,190$ & $-0,189$ & 0,024 & $-0,198$ \\
\hline $\begin{array}{l}\text { Besar } \\
\text { keluarga } \\
\text { (orang) }\end{array}$ & $-0,044$ & 0,059 & $-0,196$ & $-0,079$ \\
\hline $\begin{array}{l}\text { Lama } \\
\text { pendidikan } \\
\text { istri (tahun) }\end{array}$ & 0,141 & 0,139 & $-0,116$ & $-0,054$ \\
\hline $\begin{array}{l}\text { Pendapat- } \\
\text { an keluarga } \\
\text { (Rp/kap/bul } \\
\text { an) }\end{array}$ & 0,368 & $-0,357$ & $-0,149$ & 0,077 \\
\hline $\begin{array}{l}\text { Pengelua- } \\
\text { ran } \\
\text { keluarga } \\
\text { (Rp/kap/bul } \\
\text { an) }\end{array}$ & $-0,169$ & $0,405^{\star}$ & 0,154 & 0,098 \\
\hline $\begin{array}{l}\text { Letak } \\
\text { geografis } \\
(0=\text { perdesa } \\
\text { an, } 1=\text { perko } \\
\text { taan) }\end{array}$ & $-0,009$ & 0,129 & 0,107 & 0,102 \\
\hline $\begin{array}{l}\text { Kerentanan } \\
\text { konsumen }\end{array}$ & $-0,341^{* *}$ & $-0,180$ & $-0,230$ & $-0,362^{* *}$ \\
\hline F-hitung & 4,045 & 3,418 & 1,645 & 5,032 \\
\hline $\operatorname{Adj} . R^{2}$ & 0,213 & 0,176 & 0,054 & 0,263 \\
\hline$p$-value & $0,001^{* *}$ & $0,003^{* *}$ & 0,137 & $0,000^{* *}$ \\
\hline
\end{tabular}

Keterangan:

A: susu dan olahannya

$B: m a k a n a n$ ringan

C: Mie instan

D: pengeluaran makanan kemasan

*signifikan pada $p<0,05$

**signifika pada $p<0,01$

\section{PEMBAHASAN}

Secara umum penelitian ini bertujuan untuk menganalisis pengaruh Kerentanan Konsumen terhadap perilaku pembelian. Pada penelitian ini, perilaku pembelian meliputi jenis produk yang dibeli, frekuensi, dan pengeluaran untuk pembelian produk makanan kemasan. Berdasarkan survei sebelum penelitian, jenis produk makanan kemasan yang sering dibeli oleh rumah tangga, baik di perkotaan maupun perdesaan adalah susu dan olahannya, makanan ringan, makanan kaleng, makanan bayi, dan mie instan. Setelah penelitian diperoleh data bahwa rumah tangga di perkotaan dan perdesaan sebagian besar mengonsumsi produk susu dan olahannya, makanan ringan, dan mie instan. Oleh karena itu, untuk pembahasan selanjutnya difokuskan pada ketiga produk tersebut. 

Frekuensi pembelian adalah seberapa sering rumah tangga membeli makanan kemasan. Frekuensi pembelian susu dan mie instan pada rumah tangga di perdesaan mempunyai persentase yang lebih tinggi dibandingkan di perkotaan. Hal ini berarti rumah tangga di perdesaan lebih sering melakukan pembelian ketiga produk tersebut dibandingkan rumah tangga di perkotaan. Frekuensi pembelian di perdesaan yang lebih tinggi didasarkan pada kebiasaan rumah tangga perdesaan yang cenderung membeli produk susu dan mie instan dalam bentuk kemasan ekonomis atau membeli per kemasan setiap hari. Sementara itu, rumah tangga di perkotaan cenderung memiliki kebiasaan untuk melakukan pembelian semua kebutuhan dalam satu bulan sekaligus sehingga rumah tangga di perkotaan memiliki frekuensi pembelian yang lebih rendah dibandingkan rumah tangga di perdesaan.

Secara etimologi, kerentanan berarti peluang terluka secara fisik atau terbuka terhadap suatu serangan, bahaya atau kerusakan. Kerentanan konsumen merupakan kemungkinan konsumen menjadi mudah atau cepat dirugikan (Mascarenhas, 2007). Kerentanan konsumen juga dikaitkan dengan tingkat literasi konsumen, diantaranya adalah pengetahuan tentang hak konsumen dan praktik pemasaran, serta keterampilan interpersonal untuk mengajukan protes (Adkins \& Ozzane, 2005). Pada penelitian ini ukuran kerentanan konsumen dilihat dengan pengetahuan tentang sumber informasi penyelesaian permasalahan konsumen, pengetahuan tentang hak-hak konsumen, dan keterbukaan praktik perdagangan. Kerentanan rumah tangga di perkotaan berbeda signifikan dengan kerentanan rumah tangga di perdesaan. Hasil penelitian menunjukkan bahwa skor rata-rata kerentanan ibu rumah tangga di perkotaan lebih rendah dibandingkan ibu rumah tangga di perdesaan. Hasil ini sesuai dengan penelitian sebelumnya yang menyatakan bahwa penduduk di perdesaan lebih rentan dibandingkan di perkotaan (Franzak, Smith, \& Desch, 1995; Sprng, 1995; Scammon, Li, \& Williams, 1995; Elizabeth \& Smith,1997; Baker, Stephes, \& Hill, 2001).

Rumah tangga di wilayah perdesaan mempunyai kerentanan konsumen yang lebih tinggi daripada rumah tangga di perkotaan. Kerentanan rumah tangga di perdesaan yang lebih tinggi dapat disebabkan karena konsumen di perdesaan cenderung berpendapatan rendah, memiliki tingkat literasi yang rendah, memiliki kesadaran yang rendah terhadap merek, mendapatkan informasi yang tidak seimbang, fasilitas komunikasi dan transportasi yang tidak memadai, kurang komunikatif, konservatif (berorientasi pada kepuasan), mengambil keputusan secara lambat, memiliki kemampuan belajar dan mengevaluasi yang lambat, serta sensitif terhadap harga (Franzak, Smith, \& Desch, 1995; Scammon, Li, \& Williams, 1995; Baker, Stephens, \& Hill, 2001; Kumar \& Joseph, 2014; Anilkumar \& Joseph, 2015). Hal-hal tersebut yang menyebabkan keterbatasan pengetahuan, mobilitas dan akses informasi sehingga konsumen di perdesaan lebih rentan terhadap penipuan atau mendapatkan perlakuan yang tidak adil dalam perdagangan.

Chadah dan Misra (2010) dalam seminar Rural consumers in globalizing market juga menjelaskan bahwa konsumen di perdesaan jauh lebih rentan dibandingkan perkotaan. Konsumen di perdesaan tidak dapat dilihat sebagai kelompok yang homogen. Petani, perempuan, dan lainnya di daerah perdesaan memiliki masalah tertentu. Kebijakan harus dirancang sedemikian rupa sehingga setiap segmen terlindungi. Oleh karena itu, kebijakan harus fokus pada ketentuan-ketentuan khusus untuk melindungi konsumen. Faktor kebijakan yang tidak diteliti dalam penelitian inilah yang diduga juga dapat memengaruhi kerentanan konsumen di wilayah perdesaan.

Hasil penelitian menunjukkan bahwa kerentanan konsumen berpengaruh negatif dan signifikan terhadap pengeluaran susu dan olahannya serta pengeluaran makanan kemasan. Hal tersebut menunjukkan bahwa penurunan kerentanan konsumen akan menyebabkan peningkatan pengeluaran per kapita makanan kemasan. Kerentanan konsumen yang rendah salah satunya disebabkan oleh banyaknya informasi yang dimiliki konsumen tentang makanan kemasan, sehingga konsumen tidak mudah dirugikan dan merasa posisinya kuat dalam jual beli. Pengetahuan dan informasi yang dimiliki oleh konsumen tersebut kemudian mendorong pengeluaran makanan kemasan menjadi lebih tinggi.

\section{SIMPULAN DAN SARAN}

Kerentanan konsumen berbeda secara signifikan antara konsumen di perkotaan dan perdesaan, baik ditinjau per dimensi kerentanan maupun secara keseluruhan. Rumah tangga di wilayah perdesaan cenderung lebih rentan di-bandingkan dengan di perkotaan, terutama pada dimensi 
pengetahuan tentang sumber informasi cara mengatasi permasalahan.

Perilaku pembelian makanan kemasan antara rumah tangga di perkotaan dan perdesaan Bogor cenderung sama dalam hal jenis makanan dan frekuensinya, yang mana tiga produk terbanyak adalah susu dan olahannya, makanan ringan dan mie instan dan frekuensinya antara 1-25 kali dalam sebulan. Pengeluaran per kapita produk makanan kemasan berbeda signifikan antara rumah tangga di kedua wilayah, yang mana pengeluaran di perkotaan lebih tinggi.

Lokasi geografis berpengaruh negatif signifikan terhadap Kerentanan konsumen. Pengeluaran keluarga berpengaruh positif signifikan pada pengeluaran makanan ringan. Kerentanan konsumen berpengaruh negatif signifikan terhadap pengeluaran susu dan olahannya dan makanan kemasan. Kerentanan konsumen yang rendah terjadi karena konsumen sudah mengetahui informasi tentang makanan kemasan dengan baik. Oleh karena itu, konsumen tidak mudah dirugikan sehingga mendorong pengeluaran makanan kemasan tinggi.

Penelitian ini tidak memfokuskan pada satu produk makanan kemasan sehingga untuk penelitian selanjutnya diharapkan memfokuskan pada satu produk saja. Berdasarkan penelitian kerentanan konsumen, dimensi pengetahuan konsumen tentang sumber informasi terkait penyelesaian permasalahan konsumen adalah titik lemah ibu rumah tangga di wilayah perkotaan maupun perdesaan menjadi semakin rentan. Oleh karena itu, diperlukan edukasi tentang cara penyelesaian permasalahan konsumen dan pengenalan serta pemberian informasi tentang badan perlindungan konsumen terutama di wilayah perkotaan dan perdesaan. Ibu rumah tangga juga diharapkan lebih aktif untuk mencari informasi terkait penyelesaian permasalahan konsumen. Hal ini diharapkan agar dapat mengurangi tingkat kerentanan konsumen ibu rumah tangga dan masyarakat terutama di wilayah perdesaan.

\section{DAFTAR PUSTAKA}

Adkins, N. R., \& Ozanne, J. L. (2005). Critical consumer education: Empowering the lowliterate consumer. Journal of Macromarketing, 25(2), 153-162.

Anilkumar, N. S., \& Joseph, J. (2015). Contrasting evaluation of consumer purchase attitude - behavior urban - rural working women consumers towards whitebrown durables: A study with specific relevance to Kochi, Kerala. Journal of Global Economics, 3(2), 142. doi: 10.4172/ 2375-4389.1000142.

[BKKBN] Badan Koordinasi Keluarga Berencana Nasional. (1996). Badan Kebijakan Program Keluarga Berencana Nasional. Jakarta, ID: BKKBN.

[BPOM] Badan Pengawas Obat dan Makanan. (2012). Database Registrasi Produk Pangan. Jakarta ID: BPOM. Diambil dari http://www.pom.go.id/webreg/index.php/ho me/produk/13/row/10/page/1/order/4/DES C [Diunduh pada 20 Maret 2012].

Baker, S. M., Stephens D. L., \& Hill, R.P. (2001). Marketplace experiences of consumers with visual impairments: beyond the americans with disabilities act. Journal of Public Policy \& Marketing, 20(2), 215-224.

Baker, S. M, Gentry, J. W., \& Rittenburg, T. L. (2005). Building understanding of the domain of consumer vulnerability. Journal of Marketing, 25(2), 1-12.

Chadah, S., \& Misra, S. (2010). Rural consumers in globalizing market: vulnerability and choice. The Center for Consumer Studies. New Delhi, India.

Craig, C. S., \& Douglas S. P. (2011). Empowering rural consumers in emerging markets. International Journal of Emerging Markets, 6(4), 382-393.

Elizabeth, C. M., \& Smith, N. C. (1997). Ethichs and target marketing: The role of product harm and consumer vulnerability. Journal of Marketing, 61(3), 1-20.

Engel, J.F., Blackwell, R.D., Miniard, P.W. (1995). Perilaku konsumen Jilid I. Jakarta, ID: Bina Rupa Aksara.

Franzak F. J., Smith, T. J., \& Desch, S. E. (1995). Marketing cancer care to rural resindents. Journal of Public Policy \& Marketing, 14(spring), 76-82.

Kumar, N. A., \& Joseph, J. (2014). A Study on consumer behavior towards FMCG products among the rural-suburban ths of Ernakulam. Journal of Global Economics, 2, 127. doi: 10.4172/2375-4389.1000127.

Langerderfer, J., Shrimp, T. A. (2001). Consumer vulnerability to scams, swindles, and fraud: A new theory on visceral influences on pers. Psychology and Marketing, 18(7), ABI Inform Complete pg. 763. 
Lee, J., \& Soberon-Ferrer, H. (1997). Consumer vulnerability to fraud: influencing factors. The Journal of Consumer Affairs, 31(1), $\mathrm{ABI}$ Inform Complete pg. 70.

Mascarenhas, O. A. J. (2007). Responsible Marketing: Concepts, Theories, Models, Strategies and Cases. USA: Roval Publishing Co.

Scammon, D. L., Li, L. B., \& Williams, S. D. (1995). Increasing the supply of providers for the medicallu underserved: Marketing and Public Policy Issues. Journal of Public Policy \& Marketing, 14(Spring), 35-47.
Walsh, G., Mitchell, V.W., Kilian, T., \& Miller, L. (2010). Measuring consumer vulnerability to perceived product-similarity problems and its consequence. Journal of Marketing Management, 26(1-2), 146-162.

Zameer, H., Saeed, R., Abass, R. (2012). Mobile phone buying behavior of consumers: A comparative study of rural and urban consumers in Pakistan. Global Journal of Management and Business Research, 12(6). 